\title{
Peran Penyerapan Literasi Keuangan Terhadap Kesejahteraan Keuangan Generasi Milenial pada Masa Pandemi Covid-19
}

\author{
The Role of Financial Literacy Absorption on The Financial Well-Being \\ of Millennials during the Covid-19 Pandemic
}

Oleh:

\author{
Parulian 1); Emmelia Tan' ${ }^{2)}$ \\ "Universitas Pelita Bangsa" 1,2) \\ parulian@pelitabangsa.ac.id1); emmelia_tan@pelitabangsa.ac.id²)
}

\begin{abstract}
ABSTRAK
Pandemi COVID-19 menekan pertumbuhan ekonomi Indonesia termasuk mempengaruhi keuangan generasi milenial pekerja. Literasi keuangan yang baik akan membantu individu terhindar dari masalah keuangan, terutama selama pandemi COVID-19. Literasi keuangan dapat memfasilitasi individu untuk mengelola pendapatannya dengan baik bahkan dalam situasi pandemi COVID-19. Penelitian ini bertujuan untuk menganalisis bagaimana literasi keuangan membantu dalam kondisi pandemi COVID-19. Penelitian ini mengambil sampel sebanyak 100 responden dari generasi milenial. Penelitian ini menggunakan analisis partial least square (PLS) dengan SmartPLS. Hasil penelitian menunjukkan bahwa variabel sikap keuangan dan perilaku keuangan masa lampau berpengaruh positif terhadap literasi keuangan di masa krisis, namun variabel sikap keuangan dan perilaku keuangan masa lampau tidak ditemukan berpengaruh terhadap kesejahteraan finansial secara langsung. Implikasi dari penelitian ini adalah kemampuan literasi keuangan dari kesadaran sikap dan perilaku keuangan,
\end{abstract}

Kata Kunci: literasi keuangan; sikap keuangan; perilaku keuangan; kesejahteraan finansial

\begin{abstract}
Covid-19 Pandemic have a worse impact on Indonesia economy, inevitable financial condition among millennial working generations. Having good financial literacy can avoid financial problems/distress, especially during the covid-19 pandemic. Financial literacy can enhance an individual to manage their income well, even in a worse situation. This study aims to analyze how the implementation of financial literacy helps individuals during the covid-19 pandemic. The sample study is 100 individuals from the millennial generation. This study uses PLS (partial least square) method to analyze the data by using SmartPLS. The results show that past financial attitude and past financial behavior significantly influence financial literacy under challenging times. Meanwhile, the variable of past financial attitude and financial behavior has not directly affected financial well-being. The implication of this study is financial literacy from the awareness of financial attitude and financial behavior.
\end{abstract}

Keywords: financial literacy; financial attitude; financial behavior; financial wellbeing 


\section{PENDAHULUAN}

Setelah virus covid-19 melanda dunia dan dinyatakan sebagai pandemi oleh WHO, berikutnya di Indonesia mulai mengumumkan pemberlakuan Pembatasan Sosial Berskala Besar (PSBB) bulan Maret 2020 untuk menahan laju penyebaran virus SARS covid-19. Dampak pandemi covid-19 signifikan bagi perlambatan roda perekonomian Indonesia. Seiring dengan perlambatan roda ekonomi, penghasilan dari keluarga atau individu juga mulai merasakan kesulitan atau hambatan keuangan baik secara langsung dan tidak langsung. Sebagian besar masyarakat Indonesia tidak siap menghadapi krisis ekonomi yang disebabkan oleh adanya pandemi covid-19, terutama individu yang tidak memiliki kesiapan di saat krisis keuangan atau terlihat yang selama ini literasi keuangannya rendah. Lain hal, bagi anggota keluarga atau individu yang sudah mempersiapkan diri dengan baik misalnya memiliki dana darurat, pada saat krisis seperti ini bisa dijalani dengan tenang. Ada hal positif dan menarik dalam penelitian Philippas \& Avdoulas (2020), dampak dari krisis keuangan akhir-akhir ini telah mempengaruhi perilaku keuangan mahasiswa di Yunani.

Penelitian ini mengambil responden dari generasi milenial yang merasakan dampak krisis ekonomi dalam usia produktifnya saat ini. Generasi Milenial yang lahir dalam rentang waktu 1981-2000 adalah generasi $Y$ yang percaya diri, modern, ekspresif, berpikir liberal, terbuka terhadap inovasi, suka tantangan dan generasi lebih muda dimanjakan dengan kepraktisan, dimana generasi ini bertumbuh seiring berkembangnya era teknologi komputer dan internet (Cwynar, 2020). Generasi milenial ini sangat merasakan manfaat dan bergantung sekali dari kemajuan teknologi melalui internet, software computer, fintech, artifisial intelijen dan lain-lain. Dengan kemajuan teknologi yang ada, generasi milenial lebih mudah mendapatkan informasi berita, edukasi, fintech, hiburan, gaya hidup, pertemanan dari sosial media dan keperluan belanja online.

Era teknologi informasi 4.0 adalah tantangan tersendiri bagi generasi milenial menghadapi kehidupan keuangan yang kompleks, dimana ada banyak kemudahan akses informasi dan tawaran beragam produk keuangan. Di masa pandemi, pasar modal Indonesia mencatatkan pembukaan rekening investor ritel yang naik sangat signifikan tetapi tidak selalu dibarengi dengan kenaikan literasi pasar modal yang baik dari investor dan ditambah masih adanya asimetri informasi. Di sisi lain generasi milenial, dalam usia produktif dan sudah memiliki penghasilan sendiri pada umumnya tidak memiliki atau menyediakan banyak waktu untuk memikirkan solusi dan masalah keuangan pribadi. Kesadaran literasi keuangan perlu ditanam sejak dini, terutama sejak mulai memiliki penghasilan sendiri demi masa depan yang lebih baik dan cerdas dalam hal keuangan. Sejak beberapa tahun lalu, pemerintah Indonesia mulai OJK sudah gencar melakukan sosialisasi edukasi keuangan kepada masyarakat seperti slogan "Sikapi Uang dengan Bijak"; "Cerdas Mengelola, Masa Depan Sejahtera". Edukasi dan sosialisasi dari OJK mengajak masyarakat pintar dan cerdas dalam menggunakan uang dan penghasilan, kemudian dapat terwujud dalam sikap bijak mengelola keuangan dan mempersiapkan masa depan dengan perencanaan keuangan.

Bagaimana sikap dan perilaku terhadap kemudahan tawaran konsumerisme gaya hidup di jaman berkembangnya teknologi keuangan terutama pada saat covid 19, dengan beragam dan mudahnya mendapatkan pinjaman online, fasilitas pembayaran paylater atau cicilan nol persen sehingga positif mendorong sisi konsumtif para milenial. Begitu juga, di jaman susah pada saat covid ini juga banyak munculnya investasi bodong dengan keuntungan yang sangat menarik, imbal hasil tinggi dan pasti, jika milenial memiliki literasi 
keuangan yang baik, tidak akan mudah tertipu serta bisa memilih investasi yang bisa dipahami hasil dan resikonya. Masalah serius di saat pandemi covid-19, adalah beberapa sektor industri yang terdampak secara ekonomi, akhirnya berimbas terhadap para pekerja sektor industri dimana para milenial bekerja, ada karyawan yang dirumahkan, tidak diperpanjang kontrak, dipotong gaji bulanan, tidak terima bonus tahunan dan lain-lain yang mengakibatkan penghasilan para milenial ada yang berkurang atau tertunda atau bahkan tidak terima penghasilan dalam beberapa bulan. Kehidupan di era new normal menyebabkan perubahan dalam kebiasaan baru dan tambahan pengeluaran dalam biaya kebersihan (masker, sanitizer, desinfectan), kesehatan tes antigen/PCR/swap, dan kebutuhan imun tubuh (vitamin, obat herbal dan medis).

Penelitian ini mencoba menganalisa pada saat krisis keuangan di masa pandemi Covid-19, bagaimana peran sikap dan perilaku keuangan dalam mempengaruhi penyerapan literasi keuangan yang pada akhirnya akan berdampak pada kesejahteraan keuangan.

\section{METODOLOGI}

\section{Pengembangan Model}

Sikap keuangan dapat dipahami sebagai kecenderungan psikologi terhadap objek, individu atau peristiwa, bersifat evaluasi dinyatakan dalam tingkatan suka atau tidak suka (Santini, F. et al., 2019). Sikap keuangan di masa lampau akan membantu individu dalam menentukan keputusannya terhadap masalah keuangan yaitu dalam hal manajemen keuangan pribadi dan solusinya. Literasi keuangan adalah keterampilan seseorang dalam manajemen keuangan praktis untuk menggunakan kemampuan dengan tepat guna secara jangka pendek dan jangka panjang. Penelitian sebelumnya menemukan bahwa sikap keuangan salah satu faktor pendahulu yang mempengaruhi literasi keuangan (OECD, 2013; Ameliawati \& Setiyani, 2018; Santini, F. et al., 2019,), perencanaan keuangan (Lusardi \& Mitchell, 2011; Atkinson \& Messy, 2012; Agarwal et al., 2015) dan kecenderungan untuk menabung (Atkinson \& Messy, 2012; Agarwal et al., 2015). Dengan demikian, penelitian ini merumuskan hipotesis pertama:

H1: Sikap keuangan secara positif mempengaruhi penyerapan literasi keuangan.

Sikap keuangan merupakan kombinasi dari konsep, pengetahuan dan keadaan pikiran, pendapat dan penilaian emosi yang saling berhubungan terkait masalah keuangan (Santini, F. et al., 2019). Sikap keuangan dapat mulai terbentuk dari pengalaman masa lampau seseorang. Sikap keuangan penting dalam pembelajaran kehidupan manusia terutama meningkatkan literasi keuangan yang berkesinambungan untuk kesejahteraan ekonomi (Rajna et al., 2011; Rai et al., 2019;). Zulfiqar dan Bilal (2016) mengungkapkan bahwa sikap keuangan secara positif mempengaruhi kesejahteraan keuangan. Dengan demikian, hipotesis kedua dirumuskan:

H2: Sikap keuangan secara positif mempengaruhi kesejahteraan keuangan.

Perilaku keuangan adalah manifestasi ketika individu memiliki harapan, motivasi dan tujuan dalam keuangan. Keputusan keuangan, dalam hal ini lebih kearah tindakan psikologi yang mempengaruhi keputusan keuangan individu secara pribadi, perusahaan dan pelaku pasar keuangan. Perilaku keuangan dibangun di atas asumsi dan gagasan perilaku dalam prinsip ekonomi di masa lampau dan menjadi kebiasaan di masa depan. Keterlibatan emosi, perasaan, sifat, kesukaan, kontrol diri, komitmen dan berbagai macam faktor lain yang melekat pada sosok manusia sebagai makhluk sosial dan berakal cerdas merupakan faktor-faktor yang saling berinteraksi satu sama lain sebagai dasar munculnya tindakan dalam membuat keputusan. 
Penelitian sebelumnya menemukan faktor perilaku keuangan yang secara signifikan mempengaruhi penyerapan literasi keuangan (Sabri et al., 2008; Mudzingiri et al., 2018; Rai et al., 2019). Begitu juga, OECD (2013) menyampaikan perilaku keuangan adalah konsep dasar yang penting dalam literasi keuangan. Oleh karena itu, hipotesis ketiga dirumuskan:

H3: Perilaku keuangan secara positif mempengaruhi penyerapan literasi keuangan

Perilaku keuangan diartikan sebagai bagaimana manusia berperilaku dalam pengaturan keuangan. Secara khusus, mempelajari bagaimana pengaruh psikologi masa lampau pada proses pengambilan keputusan keuangan individu dan organisasi. Beberapa penelitian terkait perilaku keuangan dalam perencanaan keuangan anggaran, perilaku pengeluaran/belanja, perencanaan keuangan masa depan/pensiun, perilaku menabung, manajemen hutang menjadi indikator pertanyaan dalam variabel penelitian. Cara seseorang berperilaku akan sangat mempengaruhi kesejahteraan finansialnya ke depan. Oleh karena itu, memetakan penelitian empiris dimensidimensi perilaku keuangan sangat penting dalam mengukur literasi (OECD, 2013). Penelitian sebelumnya membahas bahwa perilaku keuangan secara langsung dan tidak langsung mempengaruhi kesejahteraan keuangan (Gutter \& Copur, 2011; Mokhtar \& Husniyah, 2017; Ameliawati \& Setiyani, 2018; Younas et al., 2019). Dengan demikian, hipotesis keempat dirumuskan:

H4: Perilaku keuangan secara positif mempengaruhi kesejahteraan keuangan.

Literasi keuangan adalah konsep alat ukuran bagi individu dalam pemahaman konsep penting keuangan beserta penerapannya dalam manajemen keuangan pribadi. Mengetahui bagaimana cara membuat keputusan uang yang sehat merupakan keterampilan penting di dunia saat ini, tanpa memandang usia (Coşkuner, 2016). Literasi keuangan merupakan aspek penting dalam kehidupan untuk mencapai kesejahteraan ekonomi (Santini, F. et al., 2019). Pada akhirnya, literasi keuangan memengaruhi kesejahteraan keuangan dalam menentukan keputusan (Sabri \& Zakaria, 2015; Zulfiqar \& Bilal, 2016). Tingkat kesejahteraan keuangan biasanya diukur subjektif dengan kepuasan individu pada pendapatan/harta, kepuasan dan kebahagiaan hidup, dan menjadi independen dan aman secara keuangan (Michael Collins \& Urban, 2020). Dengan demikian, hipotesis kelima dirumuskan:

H5: Penyerapan literasi keuangan secara positif mempengaruhi kesejahteraan keuangan.

$\begin{array}{lcr}\begin{array}{lr}\text { Penyerapan } \\ \text { mencerminkan }\end{array} & \text { literasi } & \text { keuangan } \\ \text { pemahaman } & \text { pengetahuan } & \text { tambahan } \\ \text { pengata }\end{array}$
pengetahuan keuangan nyata dan aktual (Michael Collins \& Urban, 2020). Penyerapan literasi keuangan dalam perilaku keuangan sangat erat kaitannya dengan kesejahteraan keuangan. Dengan sikap dan keterampilan keuangan dalam mengelola keuangan, akan semakin mudah tercapainya kesejahteraan keuangan. Literasi keuangan individu juga mempengaruhi bagaimana cara seseorang mengatur perilaku keuangannya. Zulfiqar \& Bilal (2016) menyatakan bahwa literasi keuangan memediasi sikap terhadap kesejahteraan keuangan. Dengan demikian, hipotesis keenam dirumuskan: H6: Penyerapan literasi keuangan memediasi sikap terhadap kesejahteraan keuangan.

Kebutuhan individu dan meningkatnya kompleksitas berbagai produk keuangan membuat masyarakat perlu memiliki literasi keuangan yang mumpuni. Pengendalian diri merupakan perilaku keuangan yang tepat dan perlu dijadikan menjadi kebiasaan. Perilaku keuangan berkaitan dengan rasa tanggung jawab seseorang dalam pengelolaan keuangan. Model konseptual kesejahteraan keuangan menunjukkan dampak seseorang mampu mengelola 
dana / kas yang dimiliki dengan dapat merasa sejahtera dari segi keuangannya dan sebaliknya penurunan kesejahteraan seseorang dapat timbul akibat perilaku yang salah dalam mengelola keuangannya. Hasil penelitian sebelumnya mengungkapkan bahwa literasi keuangan memediasi perilaku keuangan dalam meraih kesejahteraan keuangan (Sabri \& Falahati, 2013; Ayuba, Saad \& Ariffin, 2015). Dengan demikian, hipotesis ketujuh dirumuskan:

H7: Penyerapan literasi keuangan memediasi perilaku keuangan terhadap kesejahteraan keuangan.

Penelitian ini dilakukan pada mahasiswa generasi milenial di Kampus Cikarang, Kab. Bekasi. Model konseptual desain penelitian dengan modifikasi model dari Rai et al., (2019) dan Santini, F. et al., (2019) dijelaskan pada Gambar 1.

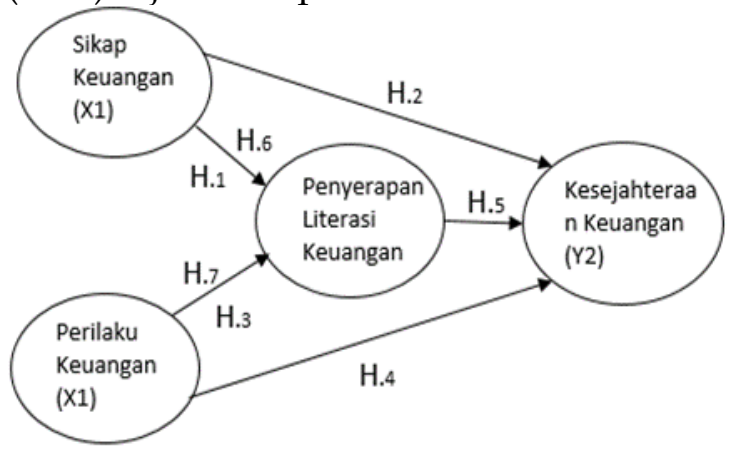

Gambar 1. Model Kerangka Konseptual

Jumlah populasi dalam penelitian ini adalah 405 pada tahun 2021 yang terdiri dari mahasiswa aktif Prodi Manajemen angkatan 2018 semester $\mathrm{V}$ tahun akademik 2020/2021 di Universitas di Cikarang. Kriteria penentuan sampel adalah mahasiswa yang lahir antara tahun 1980 2020, sudah bekerja dan berdomisili di Kab. Bekasi, Cikarang dan sekitarnya. Penelitian ini mengambil sampel 100 responden, merupakan penelitian kausal bertujuan untuk mengetahui hubungan kausal antara variabel dalam model. Pengumpulan data melalui penyebaran angket kuesioner online pada periode bulan Desember 2020 dan Januari 2021 dengan respon rate sebesar $84 \%$. Tabel 1 berikut menjelaskan profil responden yang diperoleh.
Tabel 1. Profil responden

\begin{tabular}{|c|c|c|}
\hline \multicolumn{3}{|c|}{ Jenis kelamin } \\
\hline- & Laki-laki & $59,60 \%$ \\
\hline - & Wanita & $40,40 \%$ \\
\hline \multicolumn{3}{|c|}{ Usia } \\
\hline- & 20 tahun & $8,08 \%$ \\
\hline - & 21-30 tahun & $89,90 \%$ \\
\hline- & $<40$ tahun & $2,02 \%$ \\
\hline \multicolumn{3}{|c|}{ Penghasilan } \\
\hline- & 3-5 juta & $88,89 \%$ \\
\hline - & $6-10$ juta & $10,10 \%$ \\
\hline - & $11-15$ juta & $1,01 \%$ \\
\hline- & 16-20 juta & $0 \%$ \\
\hline \multicolumn{3}{|c|}{ Pendidikan terakhir } \\
\hline- & SMA/SMK & $93,94 \%$ \\
\hline - & Diploma/Sarjana & $6,06 \%$ \\
\hline
\end{tabular}

Keempat variabel penelitian diukur menggunakan 4 skala Likert dengan pilihan (1) Sangat Tidak Setuju; (2) Tidak Setuju; (3) Setuju; (4) Sangat Setuju kriteria pertanyaan lengkap ditampilkan di Lampiran Tabel 1. Kriteria pengukuran literasi keuangan dalam penelitian ini diukur dengan objektif dan pengetahuan aktual responden dalam konsep dasar literasi keuangan yaitu: perhitungan numerik terkait suku bunga sederhana dan compound, nilai waktu uang, suku bunga kredit, resiko inflasi, investasi saham/reksadana dan asuransi.

Data penelitian di proses dengan analisis berbasis varians SEM PLS melalui aplikasi Smart-PLS untuk melihat hubungan variabel-variabel model penelitian. Tahapan SEM-PLS dengan mengestimasi model pengukuran kemudian model struktural. Estimasi model pengukuran dilaksanakan evaluasi hubungan antara konstruk dan indikatornya dalam nilai reliabilitas dan validitas. Reliabilitas menggunakan Composite Reliability dan Cronbach Alpha. Composite reliability adalah indeks yang menunjukkan keakuratan suatu alat ukur dapat diandalkan sehingga suatu variabel laten memiliki reliabilitas komposit yang sangat baik jika memiliki reliabilitas komposit dengan nilai cut off 0,7. Pada validitas dihitung dengan validitas konvergen dan validitas diskriminan. Validitas konvergen yaitu tingkat validitas 
indikator dapat dilihat berdasarkan nilai faktor pembebanan (loading factor) dan nilai rata-rata varian yang diekstrak (AVE). Nilai faktor pembebanan pada kriteria yang digunakan adalah nilai loading factor 0,50 sampai 0,60 , dinyatakan valid atau signifikan.

Prediksi kekuatan model dengan nilai R-square digunakan untuk menjelaskan berapa proporsi variabel independen mampu menafsirkan variabel dependen. Nilai R-square dapat diinterpretasikan sebagai 0,19 : lemah, 0,33 : sedang dan 0,67 : kuat ( Hair et al., 2014).

\section{HASIL PENELITIAN}

\section{Outer Model}

Hasil uji regresi PLS pada tabel 2 menunjukkan variabel dalam penelitian ini memiliki skor Composite Reliability > 0,70. Dengan demikian dapat dinyatakan instrumen penelitian reliabel sehingga dapat dilanjutkan untuk pengujian hipotesis. Perolehan Cronbach Alpha variabel $>0,60$ menyatakan bahwa kekonsistenan tanggapan survei responden pada variabel laten baik. Variabel literasi keuangan mempunyai nilai konsistensi paling rendah yaitu Cronbach alpha 0,60.

Hasil estimasi model pengukuran, loading factor dari semua indikator variabel lebih dari 0,6 ditunjukkan dalam Tabel 2, setelah dilakukan seleksi kriteria dari gambar 2 dengan menghapus kriteria yang memiliki loading factor dibawah 0,6. Dengan demikian, semua indikator variabel penelitian dapat dikatakan valid. Validitas diskriminan membandingkan akar kuadrat dari nilai rata-rata varian yang diekstrak (AVE) dari setiap variabel dengan korelasi antara variabel lain dan nilai AVE yang direkomendasikan harus lebih tinggi dari 0,50 (Solimun, 2010). Pada tabel 3 nilai AVE semua variabel penelitian sudah memenuhi kriteria valid.

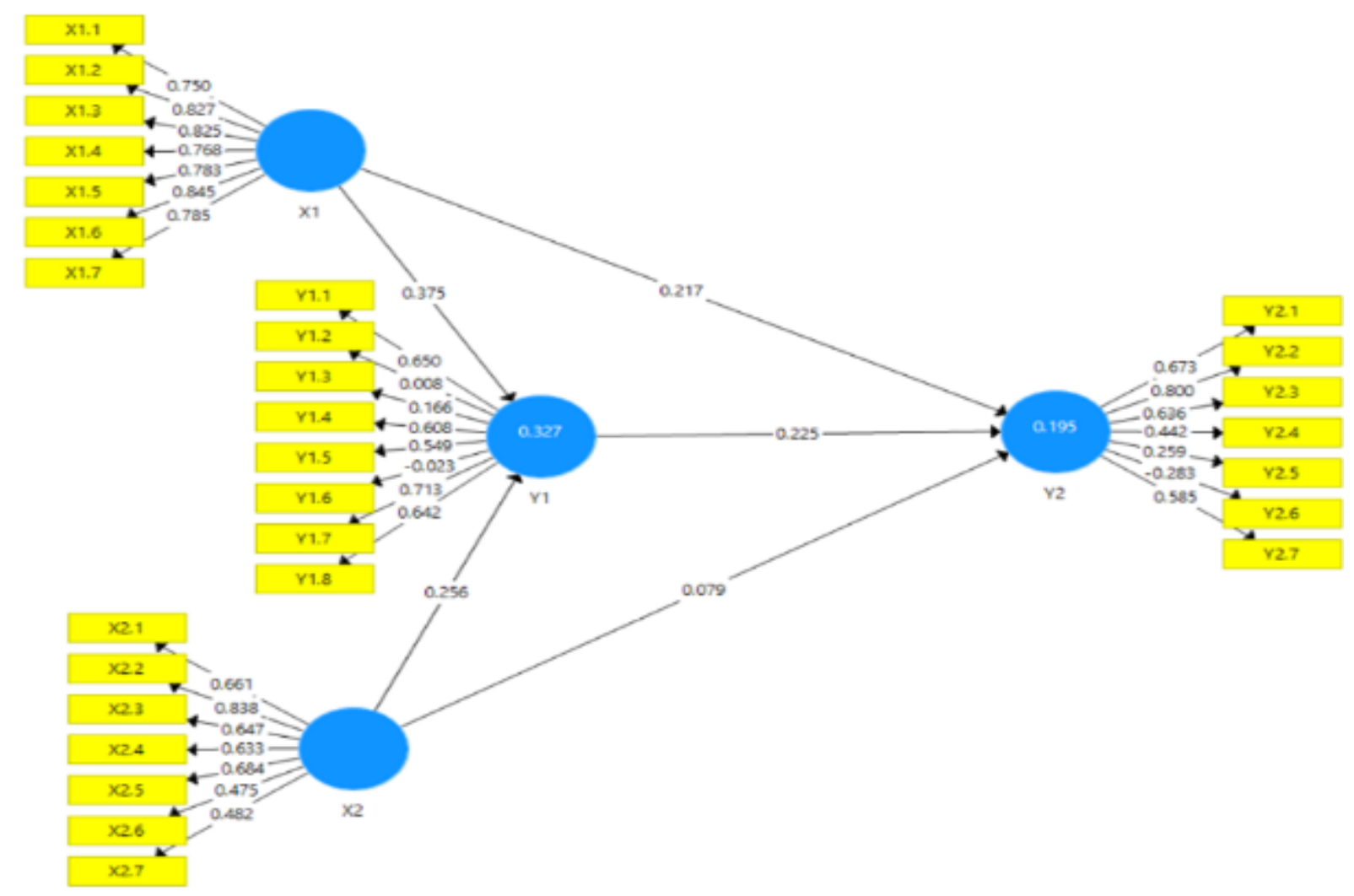

Gambar 2. Hasil uji Outer Model 
Tabel 2. Loading Factor

\begin{tabular}{|c|c|c|}
\hline & Variabel, Indikator & $\begin{array}{l}\text { Loading } \\
\text { factors }\end{array}$ \\
\hline Sikap Keı & Iangan & \\
\hline $\mathrm{X} 1.1$ & Sangat penting mengontrol pengeluaran bulanan & 0,749 \\
\hline $\mathrm{X} 1.2$ & Sangat penting merencanakan target finansial di masa depan & 0,828 \\
\hline $\mathrm{X} 1.3$ & Sangat penting untuk menabung setiap bulan & 0,830 \\
\hline $\mathrm{X} 1.4$ & Sangat penting mengikuti anggaran pengeluaran sesuai rencana & 0,770 \\
\hline $\mathrm{X} 1.5$ & Sangat penting membayar tagihan tepat waktu & 0,785 \\
\hline $\mathrm{X} 1.6$ & Sangat penting mempertahankan anggaran yang telah direncanakan & 0,840 \\
\hline $\mathrm{X} 1.7$ & Sangat penting investasi regular untuk tujuan keuangan jangka panjang & 0,782 \\
\hline
\end{tabular}

Perilaku Keuangan

X2.2 Saya menabung untuk tujuan jangka panjang (pendidikan, rumah, dll) 0,858

X2.3 Saya telah memulai dana tabungan darurat min. $3 x$ pengeluaran $\quad 0,634$

X2.4 Saya membandingkan harga di tempat berbeda saat membeli produk 0,646

X2.5 Saya membayar semua tagihan (listrik, air, telepon, dll) tepat waktu $\quad 0,792$

Literasi Keuangan

Y1.7 Asuransi kesehatan merupakan salah satu aset yang harus dimiliki $\quad 0,855$

Y1.8 Jumlah premi asuransi kesehatan yang saya bayar sesuai keinginan saya 0,838

Kesejahteraan Keuangan

Y2.1 Saya aman secara finansial sampai akhir hidup saya $\quad 0,800$

Y2.2 Saya mengamankan masa depan keuangan saya $\quad 0,791$

Y2.3 Saya telah menabung cukup uang untuk bertahan sampai akhir hidup $\quad 0,772$

Tabel 3. Validitas Diskriminan dan Composite Reliability

\begin{tabular}{lccccc}
\hline \multicolumn{1}{c}{ Variabel } & \multicolumn{2}{c}{$\begin{array}{c}\text { Validitas } \\
\text { Diskriminan }\end{array}$} & \multicolumn{3}{c}{ Composite Reliability } \\
\cline { 2 - 6 } & AVE & Deskripsi & Cronbach- $\sigma$ & Composite $R$ & Deskripsi \\
\hline Sikap Keuangan & 0,64 & Valid & 0,91 & 0,92 & Reliabel \\
Perilaku Keuangan & 0,55 & Valid & 0,74 & 0,83 & Reliabel \\
Penyerapan Literasi Keuangan & 0,72 & Valid & 0,60 & 0,83 & Reliabel \\
Kesejahteraan Keu & 0,62 & Valid & 0,70 & 0,83 & Reliabel \\
\hline
\end{tabular}




\section{Inner Model}

Hasil koefisien determinasi model akhir diperoleh nilai R-square variabel mediasi $Y 1: 0,205$ dan dependen $Y 2$ : 0,180 dapat dikategorikan lemah. Penelitian ini melakukan pengujian hipotesis dengan uji-

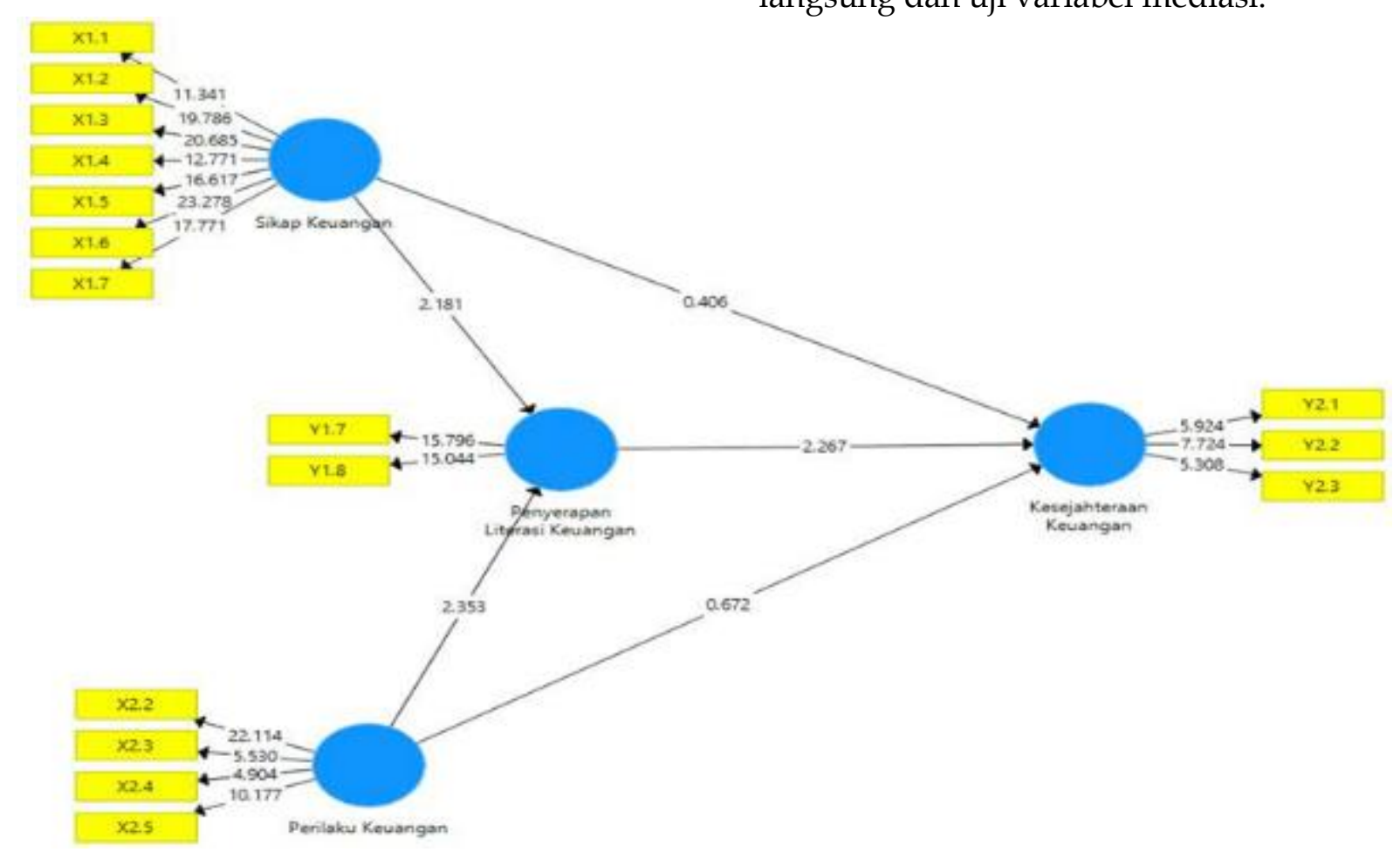

t pada setiap jalur pengaruh secara parsial langsung dan tidak langsung melalui variabel mediasi. Uji hipotesis ini dapat dipecah menjadi dua yaitu pengujian langsung dan tidak langsung. Bagian berikut menjelaskan hasil uji pengaruh langsung dan uji variabel mediasi.

\section{Gambar 3. Hasil Uji Inner Model}

Tabel 4 menunjukkan bahwa hasil pengujian hipotesis yaitu faktor sikap keuangan terbukti berkontribusi signifikan positif terhadap literasi keuangan. Hasil tersebut ditunjukkan dengan nilai koefisien jalur positif sebesar 0,256 dengan nilai P-value $<0,05$. Hasil penelitian menunjukkan bahwa semakin baik sikap keuangan yang dilakukan oleh generasi milenial maka semakin baik literasi keuangan yang dimiliki oleh generasi milenial akan bermanfaat bagi dirinya.

Sikap keuangan berkorelasi positif dan tidak berhubungan signifikan terhadap kesejahteraan finansial. Hasil ini ditunjukkan oleh koefisien jalur positif sebesar 0,075 dengan nilai $\mathrm{P}>0,05$, maka menolak H2. Hasil penelitian menunjukkan bahwa sikap keuangan generasi milenial maka kesejahteraan finansial yang dirasakan oleh generasi milenial akan semakin meningkat dan dirasakan oleh dirinya.

Perilaku keuangan terbukti memberi kontribusi positif signifikan terhadap literasi keuangan. Hasil tersebut ditunjukkan dengan koefisien jalur positif sebesar 0,240 dengan nilai $\mathrm{P}<0,05$ sehingga mendukung $\mathrm{H} 3$. Singinifikansi hasil penelitian artinya semakin baik perilaku keuangan yang dilakukan oleh generasi milenial maka akan semakin bermanfaat pula penerapan literasi keuangan.

Perilaku keuangan tidak signifikan berpengaruh positif terhadap kesejahteraan finansial. Hasil ini ditunjukkan oleh koefisien jalur negatif sebesar 0,116 dengan nilai P-value $>0,05$, sehingga tidak mendukung $\mathrm{H} 4$. Hasil penelitian menunjukkan bahwa perilaku keuangan belum signifikan berpengaruh terhadap pencapaian kesejahteraan 
keuangan yang dirasakan oleh generasi milenial untuk diri mereka sendiri.

Penyerapan literasi keuangan memiliki efek positif signifikan terhadap kesejahteraan finansial. Hasil tersebut ditunjukkan oleh koefisien jalur positif sebesar 0,315 dengan nilai P-value $<0,05$ sehingga mendukung $\mathrm{H} 5$. Semakin baik penyerapan literasi keuangan yang dilaksanakan oleh generasi milenial maka tentu akan semakin meningkatkan kesejahteraan keuangan yang dirasakan.

Tabel 4. Hasil koefisien jalur untuk pengaruh langsung.

\begin{tabular}{clccccc}
\hline Hypo & \multicolumn{1}{c}{ Variabel } & $\begin{array}{c}\text { Koefisien } \\
\text { Jalur }\end{array}$ & t-value & t-tabel & p-value & Hasil \\
\hline 1 & $\begin{array}{l}\text { Sikap Keu } \rightarrow \text { Penyerapan } \\
\text { Literasi Keuangan }\end{array}$ & $0,256^{* * *}$ & 2,181 & 1,96 & 0,03 & Signifikan \\
\hline 2 & $\begin{array}{l}\text { Sikap Keu } \rightarrow \text { Kesejahteraan } \\
\text { Keu }\end{array}$ & 0,075 & 0,406 & 1,96 & 0,69 & Non Signifikan \\
\hline $3 \quad \begin{array}{l}\text { Perilaku Keu } \\
\rightarrow \text { Penyerapan Literasi Keu }\end{array}$ & $0,240^{* * *}$ & 2,353 & 1,96 & 0,02 & Signifikan \\
\hline 4 & $\begin{array}{l}\text { Perilaku Keu } \\
\rightarrow \text { Kesejahteraan Keu }\end{array}$ & 0,116 & 0,672 & 1,96 & 0,50 & Non Signifikan \\
\hline 5 & $\begin{array}{l}\text { Penyerapan Lit. Keu } \rightarrow \\
\text { Kesejahteraan Keu }\end{array}$ & $0,315^{* * *}$ & 2,267 & 1,96 & 0,02 & Signifikan \\
\hline
\end{tabular}

\section{Pengujian Tidak Langsung}

Pengujian hubungan tidak langsung dari variabel mediasi yakni penyerapan literasi keuangan dalam memediasi sikap keuangan dengan perilaku keuangan terhadap kesejahteraan finansial. Hasil pengujian hipotesis dapat dilihat pada Tabel 5.

Tabel 5. Rekapitulasi Hasil Pengujian Variabel Mediasi

\begin{tabular}{|c|c|c|}
\hline Нурс & Alur & $\mathrm{p}$-values catatan \\
\hline 6 & $\begin{array}{l}\text { Sikap } \rightarrow \\
\text { Penyerapan } \\
\text { literasi } \\
\rightarrow \text { Kesejahteraan } \\
\text { keuangan }\end{array}$ & $\begin{array}{cc}0.69 & \text { Mediasi } \\
\text { (non sig) } & \text { parsial }\end{array}$ \\
\hline 7 & $\begin{array}{l}\text { Perilaku } \\
\rightarrow \text { Penyerapan } \\
\text { literasi } \rightarrow \\
\text { Kesejahteraan } \\
\text { keuangan }\end{array}$ & $\begin{array}{cc}0.50 & \text { Mediasi } \\
\text { (non sig) } & \text { parsial }\end{array}$ \\
\hline
\end{tabular}

Informasi yang dikumpulkan dari Tabel 5 merupakan hasil pengujian variabel mediasi, menyatakan bahwa sikap keuangan terhadap kesejahteraan keuangan melalui penyerapan literasi keuangan positif namun tidak signifikan. Temuan ini memberikan petunjuk bahwa variabel penyerapan literasi keuangan bukan sebagai faktor penentu utama sikap keuangan pada kesejahteraan keuangan sehingga masih ada faktor lain diluar model penelitian yang bisa memediasi hubungan ini. Informasi lain yang dapat disampaikan adalah pengaruh mediasi penyerapan literasi keuangan bersifat parsial (mediasi parsial) sehingga tidak mendukung $\mathrm{H} 6$.

Literasi keuangan secara positif dapat memediasi pengaruh tidak langsung dari perilaku keuangan terhadap kesejahteraan keuangan yang positif, namun tidak memiliki nilai yang signifikan. Informasi lain yang dapat disampaikan adalah pengaruh mediasi variabel penyerapan literasi keuangan terhadap pengaruh tidak langsung perilaku keuangan terhadap kesejahteraan keuangan secara mediasi parsial tidak mendukung H7. Temuan ini memberikan petunjuk bahwa variabel penyerapan literasi keuangan bukan sebagai faktor penentu utama dalam hipotesis 7 . 


\section{PEMBAHASAN}

Hasil pengujian $\mathrm{H} 1$ secara statistik menunjukkan hubungan signifikan bahwa sikap keuangan berkorelasi positif signifikan dengan literasi keuangan. Hal ini sejalan dengan penelitian Rai et al. (2019), menemukan ada hubungan kuat dari sikap keuangan individu wanita pekerja terhadap literasi keuangan. Penelitian empiris ini konsisten dengan penelitian Santini, F. et al., (2019), Yuesti et al. (2020) dan membenarkan sikap keuangan yang baik dimiliki seseorang mampu berkontribusi positif dalam kemampuan menerapkan literasi keuangan. Misalnya, jika individu memiliki sikap positif terhadap pentingnya perencanaan dan pengelolaan keuangan, apabila dalam keadaan krisis keuangan, individu tersebut akan lebih baik dalam menghadapi ketidakpastian dan lebih mampu beradaptasi.

Hasil pengujian $\mathrm{H} 2$ mengungkapkan bahwa sikap keuangan tidak memberi efek signifikan langsung bagi kesejahteraan keuangan. Hasil empiris ini menemukan sikap keuangan generasi milenial dalam responden dimana usia mayoritas 20-30 tahun dan pendidikan mayoritas setara SMU, masih belum memiliki kesadaran mengenai sikap keuangan untuk target mencapai kesejahteraan keuangan. Temuan penelitian ini berbeda dengan penelitian terdahulu yang menggambarkan arah positif dimana sikap keuangan yang semakin baik akan semakin sejahtera secara keuangan (Cwynar, 2020; Michael Collins \& Urban, 2020; Philippas \& Avdoulas, 2020 dan Yuesti et al., 2020). Philippas \& Avdoulas (2020) mengemukan kesejahteraan keuangan adalah hasil terbaik dari sikap keuangan, sikap keuangan yang sehat dan positif akan mencapai kesejahteraan keuangan lebih tinggi. Responden generasi milenial usia muda masih belum memiliki kesadaran sikap keuangan yang baik misalnya dalam sikap mengelola keuangan. Padahal di masa pandemi COVID-19 sikap keuangan seperti mengatur pengeluaran, sikap menabung untuk dana darurat sangat penting untuk mampu menyesuaikan dengan kondisi baru dan tetap bisa melanjutkan tujuan kesejahteraan ekonomi.

Hasil pengujian $\mathrm{H} 3$ menunjukkan perilaku keuangan mampu memberi dampak positif signifikan terhadap penyerapan literasi keuangan. Bukti empiris penelitian ini membenarkan temuan terdahulu dari Rai et al. (2019), Santini, F. et al., (2019), Yuesti et al. (2020), Cwynar (2020), dan Philippas \& Avdoulas (2020). Hasil ini meyakinkan bahwa semakin baik seseorang menerapkan perilaku keuangan, maka semakin dapat mengoptimalkan pengetahuan dan penerapan literasi keuangan. Literasi keuangan penting bagi individu untuk meningkatkan kemampuan keuangan dan meningkatkan kesejahteraan keuangan saat ini dan di masa depan. Penelitian ini memberikan gambaran bahwa generasi milenial harus menyadari dan mengetahui perilaku keuangan sangat penting dan konsisten berpengaruh bagi tujuan kesejahteraan keuangan.

Hasil pengujian $\mathrm{H} 4$ mengungkapkan bahwa perilaku keuangan positif pengarunya namun tidak signifikan terhadap kesejahteraan keuangan. Hasil penelitian ini menunjukkan bahwa penerapan perilaku keuangan generasi milenial belum sampai pada tahapan mencapai target kesejahteraan keuangan sehingga tidak berpengaruh signifikan. Berbeda dengan penelitian Philippas \& Avdoulas (2020) menemukan kesejahteraan keuangan bergantung salah satunya dari perilaku keuangan mahasiswa di Yunani dengan sampel 456 kategori generasi Z. Pada prinsipnya, perilaku individu merupakan cara atau kebiasaan mengelola dana yang berkaitan dengan tanggung jawab individu tersebut dalam mengelola keuangan dengan tujuan kesejahteraan keuangan.

Hasil pengujian $\mathrm{H} 5$ membenarkan literasi keuangan menjadi faktor penentu positif dan signifikan terhadap kesejahteraan keuangan. Kemampuan 
literasi keuangan ditemukan menjadi faktor kunci dalam pengambilan keputusan keuangan dan membawa individu dalam pencapaian kesejahteraan keuangan. Hasil empiris penelitian ini menguatkan temuan hasil penelitian dari Rai et al. (2019), Santini, F. et al., (2019), Yuesti et al. (2020), dan Philippas \& Avdoulas (2020). Apabila seseorang telah mampu menerapkan pengetahuan literasi keuangan dengan baik maka semakin meningkat kesejahteraan keuangannya. Dalam penelitian ini mengukur kesejahteraan keuangan dengan subjektif sejalan dengan penelitian Michael Collins \& Urban (2020).

Hasil pengujian menunjukkan $\mathrm{H} 6$ tidak signifikan walau mediasi penyerapan literasi keuangan dengan koefisien positif antara sikap dan kesejahteraan keuangan. Hal ini sejalan dengan temuan penelitian Zulfiqar and Bilal (2016) dan Yuesti et al., (2020). Dikarenakan rendahnya tingkat literasi keuangan responden yang diambil dalam penelitian ini, hal ini bisa dijelaskan dari latar belakang pendidikan tertinggi saat ini responden yang setara SMU walaupun sedang mengambil kuliah di kampus $X$ dan mayoritas usia 20-30 tahun sejalan dengan penemuan Rai et al. (2019) pada wanita pekerja di India. Literasi keuangan memiliki dampak dalam kemampuan dan kepercayaan individu dalam bersikap dalam pengambilan keputusan keuangan yang bijak. Kesejahteraan keuangan akan meningkat seiring dengan bertambah usia dan pendapatan ke depan (Michael Collins \& Urban, 2020). Di masa pandemi Covid-19 pentingnya literasi keuangan berdampak terhadap sikap keuangan secara berkesinambungan, seseorang menyadari pentingnya pengelolaan keuangan selama produktif, misal menyisihkan dana darurat dan mengatur catatan pengeluaran dan pemasukan.

Hasil pengujian menunjukkan $\mathrm{H} 7$ tidak signifikan walau mediasi literasi keuangan dengan koefisien positif antara pengaruh perilaku keuangan terhadap kesejahteraan keuangan. Secara umum dari hasil respon terkait literasi keuangan responden dalam penelitian ini masih rendah terlihat dari beberapa kriteria terpaksa dihapus karena loading factor yang rendah dapat dilihat pada lampiran di Tabel 1. Perilaku keuangan yang baik tercermin dalam, kemampuan individu dalam menggunakan uang dengan bijak, seperti mampu mengelola tabungan, pengelolaan manajemen hutang dan kewajiban, manajemen investasi dan resiko dan mengelola pengeluaran untuk diri sendiri atau keluarga (Perry dan Morris, 2005). Adanya pengetahuan finansial akan menentukan perilaku finansial untuk manajemen penggunaan uang dengan efektif sehingga individu dapat memperoleh kesejahteraan keuangan. Literasi keuangan juga menunjukkan perilaku yang baik dalam mengelola keuangan dalam kondisi sebaik mungkin, termasuk pada saat pandemi COVID-19 sejalan dengan penelitian Yuesti et al. (2020).

\section{KESIMPULAN}

Responden dalam penelitian yaitu generasi milenial dimana mayoritas responden usia 20-30 tahun, penghasilan 35 juta, dan pendidikan setara SMU menunjukkan literasi keuangan yang masih kategori rendah, dapat dikaitkan dengan peran sikap keuangan dan perilaku keuangan masih belum terarah untuk mencapai tujuan kesejahteraan keuangan. Kemampuan literasi keuangan didukung dengan perilaku dan sikap keuangan yang sehat dan baik dapat membantu mencapai tingkat kesejahteraan keuangan secara efektif. Oleh karena itu, pembelajaran dan pemahaman keuangan harus ditingkatkan di sekolah, universitas dalam sesi khusus atau mata kuliah pengayaan. Begitu juga dalam lingkungan masyarakat bisa disosialisasikan dalam bentuk workshop/seminar untuk membantu masyarakat mendapatkan pengetahuan tentang literasi keuangan yang baik. Pendidikan keuangan adalah pembelajaran seumur hidup, tahap kritis 
pada saat generasi muda dalam usia produktif. Diharapkan generasi ini lebih menyisihkan waktu untuk refleksi sikap dan perilaku keuangan serta meningkatkan penyerapan literasi keuangan dengan baik dari berbagai sumber yang tersedia pada era teknologi 4.0. Literasi keuangan dapat berkontribusi maksimal bagi masyarakat untuk memanfaatkan produk-produk keuangan dari lembaga keuangan perbankan dan lembaga keuangan lain sesuai kebutuhan, mempermudah transaksi keuangan pribadi atau usaha. Demikian juga dengan memahami risiko dari masing-masing produk keuangan membantu masyarakat terhindar dari jebakan investasi bodong, terjebak hutang dan lainnya.

Pengembangan instrumen keuangan digital dapat menjadi instrumen untuk meningkatkan penyerapan literasi keuangan dengan program yang tepat guna dan diharapkan mendekati indeks inklusi keuangan masyarakat yang ditargetkan sebesar $75 \%$ oleh pemerintah Indonesia. Pengembangan literasi keuangan digital melalui berbagai aplikasi digital yang sedang berkembang pesat saat ini juga menjadi salah satu alternatif solusi di masa new normal.

Saran bagi penelitian terkait literasi keuangan ke depan, sebaiknya perlu di sosialisasikan terlebih dahulu perhitungan dasar literasi keuangan sesuai standar OECD sehingga responden pada saat mengisi kuesioner lebih hati-hati dalam memahami pertanyaan hitungan keuangan. Skala likert kuesioner bisa dibuatkan standar dengan skala 5 sehingga bagi responden yang ragu-ragu atau tidak mempunyai pilihan diberi pilihan jawaban pada skala 3 atau netral.

\section{DAFTAR PUSTAKA}

Agarwal, S., Amromin, G., Ben-David, I., Chomsisengphet, S., \& Evanoff, D. D. (2015). Financial literacy and financial planning: Evidence from India. Journal of Housing Economics, 27(March), 4-21. https:/ / doi.org/10.1016/j.jhe.2015.02.003

Ajzen, I. (1991). The theory of planned behavior. Organizational Behavior and Human Decision Processes, 50(2), 179-211. Retrieved from https://www.dphu.org/uploads/attachements/books/books_4931_0.pdf

Ameliawati, M., \& Setiyani, R. (2018). The influence of financial attitude, financial socialization, and financial experience to financial management behavior with financial literacy as the mediation variable. In International Conference on Economics, Business and Economic Education 2018 (pp. 811-832). KnE Publishing. https:// doi.org/10.18502/kss.v3i10.3174

Atkinson, A., \& Messy, F.-A. (2012). Measuring financial literacy: Results of the OECD/International Network on Financial Education (INFE) pilot study (OECD Working Papers on Finance, Insurance and Private Pensions Measuring Financial Literacy). OECD. https:/ / doi.org/10.1787/20797117

Ayuba, A., Saad, N., \& Ariffin, Z. Z. (2015). Interacting role of perceived service orientation on work family conflict, fuel subsidy removal and tax compliance behaviour: Evidence from Nigerian SMEs. Asian Social Science, 11(28), 226. https:// doi.org/10.5539/ass.v11n28p226

Coşkuner, S. (2016). Understanding factors affecting financial satisfaction: The influence of financial behavior, financial knowledge and demographics. Imperial Journal of Interdisciplinary Research, 2(5), 377-385.

Cwynar, A. (2020). Financial Literacy, Behaviour and Well-Being of Millennials in Poland Compared to Previous Generations: The Insights from Three Large-Scale Surveys. Review of Economic Perspectives, 20(3), 289-335. https://doi.org/10.2478/revecp-20200015 
Gutter, M., \& Copur, Z. (2011). Financial behaviors and financial well-being of college students: Evidence from a national survey. Journal of Family and Economic Issues, 32(4), 699-714. https://doi.org/10.1007/s10834-011-9255-2

Hair, J.F., Hult, G.T.M. and Ringle, C.M., Sarstedt, M. (2014) A Primer on Partial Least Squares Structural Equation Modeling (PLS-SEM), Sage Publications, New Delhi, India

Lusardi, A., \& Mitchell, O. S. (2011). Financial literacy and retirement planning in the United States. Journal of Pension Economics $\mathcal{E}$ Finance, 10(4), 509-525. https:/ / doi.org/10.1017/S147474721100045X

OECD. (2013). OECD/info toolkit to measure financial literacy and financial inclusion: guidance, corequestionnaire and supplementaryquestions. Retrieved from http:/ / www.oecd.org/finance/financial-education/Toolkit-to-measure-fin-lit2013.pdf

Collins, M. J., \& Urban, C. (2020). Measuring financial well-being over the lifecourse. European Journal of Finance, 26(4-5), 341-359. https:/ / doi.org/10.1080/1351847X.2019.1682631

Mokhtar, N., \& Husniyah, A. R. (2017). Determinants of financial well-being among public employees in Putrajaya, Malaysia. Pertanika Journal Social Science E Humanities, 25(3), 1241-1260. Retrieved from https://www.semanticscholar.org/paper/Determinants-offinancial-well-being-among-public-

Mokhtar/a967a373841cc4c65b60ce707122abed578ad499

Mudzingiri, C., Muteba Mwamba, J. W., \& Keyser, J. N. (2018). Financial behavior, confidence, risk preferences and financial literacy of university students. Cogent Economics $\mathcal{E}$ Finance, 6(1), 1-15. https:/ / doi.org/10.1080/23322039.2018.1512366

Perry, V. G., dan Morris, M. D, 2005, 'Who is in control? The role of self perception, knowledge, and income in explaining consumer financial behavior', The Journal of Consumer Affairs, Vol. 39, No. 2. 299: 313.

Philippas, N. D., \& Avdoulas, C. (2020). Financial literacy and financial well-being among generation-Z university students: Evidence from Greece. European Journal of Finance, 26(4-5), 360-381. https:/ / doi.org/10.1080/1351847X.2019.1701512

Sabri, M F, MacDonald, M., Masud, J., Paim, L., Hira, T. K., \& Othman, M. A. (2008). “Financial behavior and problems among college students in Malaysia: Research and education implication". Consumer Interests Annual, 54(1), 166-170.

Sabri, M. F., \& Falahati, L. F. (2013). Predictors of financial well-being among Malaysian employees: Examining the mediate effect of financial stress. Journal of Emerging Economies and Islamic Research, 1(3), 61-76. https:/ / doi.org/10.24191/jeeir.v1i3.9130

Sabri, M. F., \& Zakaria, N. F. (2015). The Influence of Financial Literacy, Money Attitude, Financial strain and financial capability on young employees' financial well-being. Pertanika Journal of Social Sciences $\mathcal{E}$ Humanities, 23(4), 827-848. Retrieved from https:// core.ac.uk/download/pdf/153832275.pdf\#page $=83$

Santini, F. D. O., Ladeira, W. J., Mette, F. M. B., \& Ponchio, M. C. (2019). The antecedents and consequences of financial literacy: a meta-analysis. International Journal of Bank Marketing, 37(6), 1462-1479. https:/ / doi.org/10.1108/IJBM-10-2018-0281

Solimun, 2010, Analisis Multivariat Pemodelan Struktural Metode Partial Least Square - PLS, CV. Citra Malang, Malang.

Rai, K., Dua, S., \& Yadav, M. (2019). Association of Financial Attitude, Financial Behaviour and Financial Knowledge Towards Financial Literacy: A Structural Equation Modeling Approach. FIIB Business Review, 8(1), 51-60. https:/ / doi.org/10.1177/2319714519826651 
Rajna, A., Ezat, W. P. S., Al Junid, S., \& Moshiri, H. (2011). Financial management attitude and practice among the medical practitioners in public and private medical service in Malaysia. International Journal of Business and Management, 6(8), 105. https:// doi.org/10.5539/ijbm.v6n8p105

Yuesti, A., Rustiarini, N.W., Suryandari, N.N.A. 2020. "Financial literacy in the COVID- 19 pandemic: pressure conditions in Indonesia". Entrepreneurship and Sustainability Issues, 8(1), 884-898. http://doi.org/10.9770/jesi.2020.8.1(59)

Younas, W., Javed, T., Kalimuthu, K. R., Farooq, M., Khalil-ur-Rehman, F., \& Raju, V. (2019). Impact of Self-Control, Financial Literacy and Financial Behavior on Financial WellBeing. The Journal of Social Sciences Research, 5(1), 211-218. Retrieved from https://ideas.repec.org/a/arp/tjssrr/2019p211-218.html

Zulfiqar, M., \& Bilal, M. (2016). Financial wellbeing is the goal of financial literacy. Research Journal of Finance and Accounting, 7(11), 94-103. Retrieved from https://www.iiste.org/Journals/index.php/RJFA/article/view/31504

https://sikapiuangmu.ojk.go.id/FrontEnd/CMS/Category/14 